\title{
Évreux - 2 rue de Bellevue
}

$n^{\circ} 17-981$

Frédéric Kliesch

\section{(2) OpenEdition}

\section{Journals}

Édition électronique

URL : http://journals.openedition.org/adlfi/16542

ISSN : 2114-0502

Éditeur

Ministère de la culture

Référence électronique

Frédéric Kliesch, «Évreux - 2 rue de Bellevue », ADLFI. Archéologie de la France - Informations [En ligne], Haute-Normandie, mis en ligne le 17 février 2016, consulté le 19 avril 2019. URL : http:// journals.openedition.org/adlfi/16542

Ce document a été généré automatiquement le 19 avril 2019

(C) Ministère de la Culture et de la Communication, CNRS 


\title{
Évreux - 2 rue de Bellevue
}

$n^{\circ} 17-981$

\author{
Frédéric Kliesch
}

Code INSEE commune : 27229

Lien Atlas (MCC) :

http://atlas.patrimoines.culture.fr/atlas/trunk/index.php?

ap_theme=DOM_2.01.02\&ap_bbox=1.090;48.989;1.190;49.047

1 Cette opération sur $700 \mathrm{~m}^{2}$ a livré 21 structures funéraires : 19 inhumations et 2 sépultures secondaires à crémation. Le test d'une structure a permis de mettre au jour une sépulture comprenant un coffret et un cercueil en plomb anépigraphe et sans décor, déposé dans un coffrage en bois. Elle contenait les restes d'une jeune femme.

2 Les 19 fosses subrectangulaires sont manifestement des tombes. Certaines livrent des ossements d'équidés en surface et les alignements épousent l'axe de la double sépulture testée.

3 Les structures comme les ossements sont bien conservés. La datation n'a pas été précisée en l'absence de mobilier céramique. Cependant le cercueil en plomb, aux caractéristiques analogues à celui trouvé au 3 bis rue de la Libération (Pluton-Kliesch 2008), permet de situer ces structures dans l'Antiquité.

4 Si nos tests ne portent que sur deux sépultures, l'homogénéité des remplissages, la cote d'apparition des structures, ainsi que leur forme rectangulaire, dans ce secteur où seuls des restes de natures funéraires ont été retrouvés, nous permettent d'affirmer que nous sommes au sein de la nécropole antique du «Clos au Duc ». Cette partie de la nécropole est dense et bien préservée. Aucun recoupement de structure n'a été observé, ce qui tend à prouver que les sépultures étaient signalées ou marquées. Aucun bâtiment moderne ou contemporain n'a été implanté sur la parcelle, ce qui rend toutes les connaissances nécessaires à l'exploitation scientifique des données relatives à la nécropole accessibles. 
INDEX

Index chronologique : Antiquité

Index géographique : Normandie, Eure (27), Évreux

Mots-clés : sépulture, inhumation, incinération, coffret, cercueil en plomb, coffrage, sépulture animale, cheval, nécropole

operation Diagnostic (EV)

\section{AUTEURS}

\section{FRÉDÉRIC KLIESCH}

Inrap 